Revista de Economia Política, vol. 35, n 2 (139), pp. 203-226, abril-junho/2015

\title{
Chronic macro-economic and financial imbalances in the world economy: a meta-economic view
}

ROBERT GUTTMANN*

RESUMO: As finanças globais, combinando a operação bancária offshore e bancos universais para conduzir um processo de globalização mais amplo, tem transformado o modus operandi da economia mundial. Isto exige um novo quadro "meta-econômico", em que os fluxos de carteira de investimento a curto prazo são tratados como o fenômeno dominante no qual eles se tornaram. Organizado pela finança global, esses fluxos bidirecionais em camadas entre o centro e a periferia gerenciam uma tensão entre a concentração financeira e a fragmentação monetária. Os desequilíbrios resultantes expressam as assimetrias embutidas nessa tensão e transforam a taxa de câmbio na política estratégia mais variável do que nunca.

PALAVRAS-CHAVE: finanças globais; fragmentação monetária; fluxos de dinheiro, estrutura meta-econômica; taxas de câmbio.

ABSTRACT: Global finance, combining offshore banking and universal banks to drive a broader globalization process, has transformed the modus operandi of the world economy. This requires a new "meta-economic" framework in which short-term portfolio-investment flows are treated as the dominant phenomenon they have become. Organized by global finance, these layered bi-directional flows between center and periphery manage a tension between financial concentration and monetary fragmentation. The resulting imbalances express the asymmetries built into that tension and render the exchange rate a more strategic policy variable than ever.

KEYWORDS: global finance; monetary fragmentation; hot-money flows; meta-economic framework; exchange rates.

JEL Classification: F32; F33; F44.

The world economy witnessed widespread and thorough deregulation of exchange rates and cross-border capital flows during the 1970s and 1980s, a period that saw also a major conservative policy revolution in the wake of the Reagan and

\footnotetext{
* Professor of Economics, Hofstra University, and Université Paris XII. E-mail: robert.p.guttmann@ hofstra.edu. Submetido: 21/Julho/2014; Aprovado: 31/Julho/2014.
} 
Thatcher administrations ruling the two countries with the world's largest financial centers. "Reaganomics", combining massive tax cuts for the wealthy, deregulation, privatization, cuts in public-assistance programs, weakening of unions and collective-bargaining rights, was given an international reach as the so-called Washington Consensus being imposed on developing countries in return for assistance by the IMF and US Treasury for their crisis-ridden economies. This worldwide push for free-market reforms, phenomenally successful in its planetary propagation, has offered an excellent test case for the efficacy of market-regulated adjustment mechanisms. Yet the results have been disappointing, with macro-economic and financial imbalances growing in size over those decades and showing remarkable stickiness that has defied their easy resolution.

Neither flexible exchange rates nor changes in the policy mix seemed to have been able to reduce or eliminate external imbalances in lasting fashion. Only crises, of which we have seen many instances over the last four decades, did make a dent in those imbalances in relatively speedy and durable fashion. This empirical reality defies the standard macro-economic paradigm, always a good starting point for heterodox alternatives to challenge the established dogma with a better explanation. But such an opportunity will only succeed, if that theoretical alternative can come to grips with the deep structural changes our world economy has experienced since the early 1970s. There are in particular two transformations we have to take account, the intense wave of globalization sweeping our planet and the explosive growth of financial transactions in its wake. If we can take better account of these crucial phenomena than the standard approach has done so far, then we shall have opened the way for giving our explanations greater credibility while also improving our understanding of major challenges we face today. This paper is a small attempt in the direction of such theoretical innovation to explain the persistence of external imbalances and their connection to crisis dynamics.

\section{DEFINING IMBALANCES AND ADJUSTMENT PATHS}

When macro-economic argumentation applies to open economies, it expands our understanding of a national economy's behavior by moving us beyond the domestic dual balance of private sector (savings $S$, gross business investment $\mathrm{I}_{\mathrm{g}}$ ) and public sector (taxes T, government expenditures $G$ ) to include an external sector (exports $\mathrm{X}$, imports $\mathrm{M}$ ) through which that economy is linked to rest of the world. From the essentially Keynesian spending/product equation $Y(G D P)=C+I_{g}+G+X$ and the income equation $Y=C+S+T+M$, and denoting $X_{n}$ as net exports $(X-M)$, we get:

$$
X_{n}=\left(S-I_{g}\right)+(T-G)
$$

The three sectoral balances are thus intertwined so that changes in one balance will beget compensatory changes in the other balances. For instance, a trade (or current account $)$ deficit $\left(\mathrm{X}_{\mathrm{n}}<0\right)$ may well be the result either of a private-sector 
deficit $\left(\mathrm{I}_{\mathrm{g}}>\mathrm{S}\right)$ and/or budget deficit $(\mathrm{G}>\mathrm{T})$ or a combination of both. One way to reduce such an external imbalance is to tackle the imbalances at home. You can get current account deficits under control by applying fiscal austerity to get budget deficits pushed onto a downward path - a policy prescription the 18-member eurozone seems to be very fond of these days. ${ }^{1}$ It is more difficult to do that by changing the parameters of the private sector even though monetary policy aimed at altering interest rates in prescribed doses may impact on savings and/or on investments both of which are (somewhat) influenced by interest rates.

We can also take a more pro-active view in which the external balance, best measured in the broader sense of a currentaccount balance (adding repatriated investment income and unilateral transfers to the balance of trade in goods and services), is no longer just seen as a passive residual of the private- and publicsector balances at home. Instead it becomes a self-determined balance, which after half a century of rapidly expanding trade volumes across the capitalist world having rendered a large majority of countries so much more dependent on trade may ultimately be a sensible assumption. Trade has become so important to the fortunes of the domestic economy, even in a relatively closed economy like the United States whose foreign-trade share of exports and imports in GDP rose from about 10 percent in the mid-1970s to 28 percent last year. Most countries, smaller and under more pressure to specialize, have far greater degrees of openness however, ranging from $60+$ percent in Germany to over 100 percent in, say, Belgium or the Netherlands.

And just as the external balance has become increasingly autonomous with growing self-determination in the wake of globalization, so has it also gained its own adjustment mechanism to move us beyond its traditional (passive-residual) dependence on corresponding changes in the domestic S - I and T - G balances. Ever since the US introduced a free float for the US dollar in March 1973 following the collapse of the fixed exchange rate regime known as Bretton Woods in August 1971, the world has moved gradually towards market-determined "flexible" exchange rates. Much of that movement towards greater currency-price liberalization occurred in the wake of recurrent currency crises triggered by successful speculative attacks on unsustainable "pegs" (i.e., fixed-rate currency anchors) as happened in the wake of the LDC debt crisis of 1982-89, the disintegration of the European Monetary System's fixed-rate Exchange Rate Mechanism in 1992-93, the "Tequila crisis" of the Mexican peso in 1994-95, or the "Asian Tigers" crisis of 1997-98. With varying degrees of float now the standard, deficit countries can try and let fluctuations in their exchange rates correct these external imbalances. Facing excess supplies of their currency (as the external deficit translates into net outflows), they

\footnotetext{
${ }^{1}$ The "fiscal pact" of 2011 holds eurozone members to a more strictly enforced budget-deficit limit of 3 percent of GDP than had been hitherto the case, and gives the European Commission the authority to review member's budget plans with active sanction power. Its enforcement can at same time be tailored to the specific needs of individual members.
} 
will see it depreciate whereby imports are rendered more expensive and exports become more price-competitive. These price effects from a currency depreciation should lead to volume adjustments towards more exports and fewer imports, restoring so balance in the current account.

Yet, when we look at the global statistics collected by such multilateral institutions as the International Monetary Fund and its World Economic Outlook, we see persistent current account imbalances among leading (G-20) countries as well as between or within regional blocs persist over many years. These may range from 2 percent to 6 percent of GDP, more pronounced in some countries and definitely also subject to considerable cyclical fluctuations. As a matter of fact, the prevailing state of the cycle has a consistent impact on a country's current account. During recoveries current account balances tend to deteriorate as imports often rise disproportionately (as the tend to have higher-than-average value added) in line with growing aggregate spending in the economy while exports rise less amidst a thriving home market. This inverse relation between domestic expansion and the current account gets stronger, the faster the growth. Part of that is also due to parallel changes in the domestic balances towards greater private-sector deficits (as S slides proportionately while I picks up) outweighing gradual improvements in the public sector due to growth-enhanced tax revenues. The opposite happens when the economy turns down, with current account deficits typically shrinking swiftly. Apart from these cyclical fluctuations, we do however see stubbornly persistent, hence chronic current account disequilibria. America's lasting trade deficit or the large current account surpluses of China, Germany, or Japan are much-noted examples proving that point, and there are many other examples less well known.

This persistence of external imbalances indicates that the aforementioned adjustment mechanisms do not work as they should. Yes, it may be politically too difficult for governments under pressure to impose fiscal austerity on its citizens. And a central bank's manipulation of short-term interest rates may not carry sufficiently over to the long-term interest rates shaping savings and investment decisions, if at all. Nor may currency depreciation work as prescribed in the textbooks. Trade patterns may have become quite price-inelastic, especially with non-price factors playing a growing role (e.g., quality, brand value, political determinants of preferential trade). ${ }^{2}$ Even then, I suspect that a significant part of the failure-toadjust puzzle does not have so much to do with the slow or limited workings of policy-mix or exchange rate adjustments, as it is the result of globalization itself.

\footnotetext{
${ }^{2}$ In what has become known as the Marshall-Lerner Condition, already Alfred Marshall (1879-1930) and Abba Lerner (1952) pointed to the possibility of currency depreciation having only a delayed impact on a country's external balance, thanks to price effects dominating volume adjustments in the face of relatively inelastic trade patterns. Price inelasticities pertaining to foreign trade may be so strong in the short run that the external deficit actually gets worse in the immediate aftermath of depreciation before gradually improving — the so-called "J-curve” effect first identified by Steven Magee (1973).
} 


\section{THE DOMINANCE OF THE FINANCIAL ACCOUNT}

The current account, in addition to being connected to the domestic (privateand public-sector) balances and determining exchange rates, is relevant not least also because of its influence over the capital account of the country concerned. The two are inversely related. If one is in surplus, the other is in deficit, and vice versa. Typically the causality so far has been from the current account to the capital account or more precisely financial account. ${ }^{3}$ The standard argument is that countries running trade surpluses have the means to invest abroad, hence running financial account deficits as capital exporters or net buyers of foreign assets. Countries with current account deficits, on the other hand, need to finance those by borrowing from abroad, hence importing foreign capital to yield a financial account surplus as net sellers of financial assets.

Globalization may have turned this standard argumentation on its head. Global economic expansion has been remarkable since the beginning of the accelerated globalization push thirty-five years ago. Only the systemic worldwide financial crisis of 2007-09 has slowed, and partially even reversed, this trend. We know from pre-crisis data by the Peterson Institute of International Economics (see, for instance, Matthew Adler and Gary Clyde Hufbauer, 2008) that, whereas nominal world GDP increased fourfold from 1980 to 2006, (bi-lateral) trade flows have expanded more than six-fold and the stock of foreign direct investment (FDI) has grown by about twenty times during that period. And according to the Institute for International Finance's "Capital Flow Report" (see www.iif.com/emr/global/capflows) the volume of cross-border portfolio-investment flows (loans, securities) has grown thirty-fold since 1980 . The resulting increase in the capital account of major economies, starting with the United States, may have been such that it is nowadays possible to have the capital account shape the current account, thus reversing the standard causality. Brazil, for instance, may experience sustained periods of dramatic capital inflows attracted by the super-high Selic short-term interest rate which in turn may drive up the real against other currencies and so worsen Brazil's trade balance over time - the curse of the so-called "carry trade." Of course, in reality, both accounts are likely to impact on each other from either direction at the same time; that is how the global economy works as it piles one monetary/financial circuit after another on top of each other.

But if this is the case, then we have come to the point where standard international (open-economy) macro-economics only tells part of the story and misses perhaps the most salient points about what is going on today. In other words, we need to rethink the global economy. We need a meta-economic revolution, just as

\footnotetext{
${ }^{3}$ The so-called "capital account" is narrowly defined to deal only with such relatively marginal things as transfers of user licenses, leases, and intellectual property rights, hence in actuality a very small item. That part of the capital account known as the financial account deals with direct foreign investment and portfolio investments comprising loans and securities, the key vectors of cross-border "capital" movements.
} 
Keynes launched the macro-economic revolution eight decades ago, which recognizes that the world economy is more than the sum of its parts, the national economies. Standard international macro-economics hooks any national economy under consideration (e.g., Brazil) to the "rest of the world" through its balance of payments and exchange rate, thus offering a look at the international dimension solely from the vantage point of any given country. But what if the cross-border flows of goods, services, and above all money and assets have become so large, so dominant, that they themselves create a supra-national growth dynamic integrating national economies into a new web. That is why we need to work on our metaeconomic understanding of how the world economy engenders its own growth dynamic whereby it become clearly more than the sum of its part and so escapes the analytical framework of the linear-aggregation logic of standard theory.

\section{THE EMERGENCE OF GLOBAL FINANCE}

Standard theory has another huge flaw hampering its understanding of the globalization process, its complete lack of appreciating the central role of finance. In most of its models finance simply does not exist as anything beyond a passive residual which assures the macro-economic equilibrium between savings and investments via appropriate changes in interest rates. Yet this "indirect finance" financialintermediation mechanism of attracting existing savings (via bank deposits) and turning those into investments (via supply of loanable funds), if it works at all, is nowadays but a tiny aspect of finance. Once again we need to have theoretical innovation, this time in the direction of a meso-economic viewpoint capable of appreciating finance as a "system" connecting the micro-dimension of individual actors as debtors and investors with the macro-dimension of distribution and growth. Yes, we do have to understand finance as a "system" rather than just as a collection of individual intermediaries or as a service sector next to other sectors. Otherwise we cannot understand its intertwined architecture, its linking of credit and money creation, its self-expansion capacity, what it means to have a "systemic" financial crisis. More broadly speaking, we need to have a much better sense of finance to appreciate its transformative impact as we have moved to finance-led capitalism. ${ }^{4}$

Rather than just jumping right away into the abstract world of mathematical model-making to analyze a new phenomenon, it may behove us to draw a little bit from history to trace finance's rise to the center of our global economy. The postwar boom of the 1950s and 1960s took place within a well-regulated structure of nationally administered credit-money (first introduced by Roosevelt's monetary reforms following the collapse of the gold standard in 1931), whose international

\footnotetext{
${ }^{4}$ I would like to point the reader here to my own body of work about "finance-led capitalism," from my first analysis of its systemic crisis (Robert Guttmann, 2008) and its key pillars (Robert Guttmann, 2010) to my current effort soon to appear as a book with Palgrave Macmillan (Robert Guttmann, 2015).
} 
extension - the Bretton Woods system - provided institutional support for the worldwide nature of that boom. ${ }^{5}$ Bretton Woods combined low interest rates with fixed exchange rates, an overvalued US dollar, and large-scale US capital exports - the ingredients for export-led growth by other industrial nations catching up with the US while keeping energy cheap. That system came under pressure during the stagflation crisis of the 1970s, when the combination of accelerating inflation and slowing growth eroded the wage-productivity, creditor-debtor, and publicprivate balances of the social contract underpinning that boom.

One profound expression of that destabilization process was financial innovation as the creditors sought, with increasing desperation and hence urgency, to escape the regulatory straitjacket imposed on them by the postwar monetary regime in the form of negative real interest rates, chronically maladjusted exchange rates, and associated losses from the debt-inflation spiral driving the stagflation crisis. Politically, the creditor community organized around the banks whose crucial role as principal credit intermediary, privileged protectorate of the government, and managers of the payments system of our cash-flow economy had endowed them early on with special powers and unique influence. ${ }^{6}$ And while banks have always been able to organize as powerful lobbies dominating the representatives of the metropolis (as "financial center") and capturing key government institutions (central bank, financial-market regulator), one of their key channels in which they made their weight felt was financial innovation. And here the stagflation crisis and its interaction with the disintegrating Bretton Woods system spawned two crucial innovations - Eurocurrencies and wholesale funding in money markets - which together propelled global finance to the fore as a strategic determinant of how the world economy came to organize globalization and uneven development.

In the late 1950s London-based banks accepted to offer dollar-denominated time deposits and loans. This innovation, known at first as the Eurocurrency "market" and later as offshore banking, created in one swoop a new global private banking network, with its own payments system (anchored in two electronic-fund and data-transfer networks known as CHIPS and SWIFT), that had the liberty of operating beyond the reach of national central banks and devoid of regulatory restrictions. That network grew very rapidly, at a 20 percent average every year, by absorbing Bretton Woods' rapid build-up of excess dollars in international circulation. Another reason for its rapid expansion beyond Bretton Woods was its irresistible competitiveness. In the absence of regulatory restrictions (which are a tax-like cost), Eurobanks could offer higher deposit rates and lower loan rates than domestic banks while still earning a bigger profit margin (i.e., "spread"). They could also experiment freely with new debt instruments (e.g., floating-rate notes, emergingmarket bonds) and new institutional structures (e.g., fusion of commercial and

\footnotetext{
${ }^{5}$ For more information on this well-regulated post-war monetary regime see Robert Guttmann (1994).

${ }^{6}$ Excellent analyses of the power of banks can be found in Kevin Phillips (2008) as well as Simon Johnson and James Kwak (2010).
} 
investment banking), thereby becoming the primary vector for the transformation of financial capital we have witnessed over the last three decades. ${ }^{7}$

Offshore banking, while itself the institutional pillar of global finance, is also tied to another profound change in how our credit system has come to operate the emergence of money markets. The US banking system introduced during the 1960s a series of tradable short-term debt instruments - negotiable certificates of deposit, commercial paper, bankers' acceptances, loanable bank reserves known as "federal funds", etc. - to give its members access to additional funds on short notice. Having US-based banks borrow Eurodollar deposits from foreign affiliates was part of that emerging system of "money markets." Those were given a huge boost in 1975 with the introduction of money-market funds, whose shares at a guaranteed net value compete effectively with bank deposits and so collect huge amounts of savings to invest across the entire range of money-market instruments. ${ }^{8}$ The presence of money markets has completely transformed the way banks operate. Beforehand banks had to keep a lot of highly liquid (and correspondingly loweryielding) assets around, such as cash reserves or T-bills, in order to meet unforeseen deposit withdrawals on their liability side. The emergence of money markets liberated the banks from this liquidity constraint by giving them immediate access to funds beyond their deposit base. So they could instead set aggressive asset-growth targets and then scramble for funds in the money markets to fill any funding gaps that may arise. By accessing such borrowed funds on short notice the banks could operate far beyond their government-regulated deposit base ("retail funding") and grow a lot faster. That access to wholesale funding also laid to rest the orthodox notion that the banks' endogenous money-creation process - and with it the money supply - could be controlled by the central bank. The new market-mediated money creation capacity of banks got powered up significantly by "repos" (i.e., repurchasing agreements), a market for secured short-term loans, where banks and others can turn their securities into money.

\section{UNIVERSAL BANKS}

These two innovations - offshore banking as a global private banking network and wholesale funding via money markets - intermingled to create a global banking system on steroids. Unconstrained by regulatory restrictions, the wholesale-funded offshore-banking network could evolve freely in its multi-functional

\footnotetext{
${ }^{7}$ To what extent Eurocurrencies constitute money has been a hotly debated topic ever since their inception. See in this regard the very interesting discussion in Edward Frydl (1982).

${ }^{8}$ Money-market funds invest in a large variety of short-term money-market instruments, thus providing funds to various money markets. They offer their shareholders money-market rates as returns. By promising to keep their net asset value at one dollar per share, they provide investors with a value guarantee that compensates for the comparative lack of deposit insurance. These funds also offer their investors typically limited check-writing privileges.
} 
structure. Commercial banking, the classic intermediation process of indirect finance taking deposits and making loans, soon came to be extended by additional dimensions of global finance.

1. Market Finance: Boosted by money markets, investment banks created a variety of new financial markets or extended existing ones geographically by acting as brokers, dealers, underwriters, and stabilizers of tradable instruments - bonds, stocks, derivatives, currencies, money-market instruments, and asset-backed securities. This market finance was nourished by institutional investors in the form of various investment pools ("funds") - pension funds, mutual funds, hedge funds, private-equity funds - whose shares replaced bank deposits as the preferred channel of the world's savings. Promising higher, but also variable returns to individual and corporate investors, the funds became the vehicle par excellence for the transformation of (conservatively inclined) savers into (risk- and return-seeking) speculators, a new class of rentiers in the driver's seat across the world.

2. Network Finance: Many of the new markets were not organized as public exchange, but as "over-the-counter markets" which function more like insider networks of bilateral deal-making, privately controlled price (in)formation, and multiple intermediation chains for the transfer of various risks. Such network finance may group together smaller non-bank institutions (e.g., money-market funds, finance companies, hedge funds) to scale up collectively in their competitive battles with the larger commercial banks. But network finance is still dominated by the banks. As a matter of fact, the world's leading banks, the so-called primary dealers selected by the Fed for privileged access as counterparties in its open-market operations, form themselves a network which functions like a cartel (as also evidenced by their involvement in recent market-manipulation scandals concerning Libor and key exchange rates). They have extended this network web to the world's remaining banks via the correspondent system and the global inter-bank market. And from 1988 onward the banks built increasingly complex shadow-banking networks to move much of their operation off their balance sheets once those had come under supervisory and regulatory control of the BIS-led consortium of banking regulators in the wake of a global banking regulation effort known as the Basel Agreements. 9

Being able to expand their operations at will in offshore banking, the banks obtained their goal of removing structure regulations like Glass-Steagall's 1933 separation of commercial banking and investment banking, first with the EU's Second Banking Directive in 1989 and then with the Gramm-Bliley-Leach Financial Services Modernization Act of 1999 in the US. These far-reaching deregulation initiatives accelerated the integration of commercial banking, investment banking, insurance, and asset management (both funds and private investors) under one roof,

\footnotetext{
${ }^{9}$ The Basel-based Bank for International Settlements (BIS) is an umbrella organization of the world's leading central banks. As such it has become the key conduit for efforts at global banking regulation, starting with the Basel Accord of 1988 providing for a minimum risk-weighted capital-asset ratio. That agreement has been amended twice, and these extensions are known as Basel II (2004) and Basel III (2010).
} 
giving so rise to the so-called universal banks which integrated the different functions of finance to reap scale, scope, and network economies and also to extract a variety of (cartel-based) monopoly rents in the form of fees, commissions, and arbitrage profits which supplement their already considerable financial income of net interest, dividends, and capital gains.

\section{FINANCIAL CONCENTRATION AND MONETARY FRAGMENTATION}

Global finance, with its pillars of offshore banking, wholesale funding, and universal banks, has served as spearhead of globalization for over four decades now, promoting trade, direct foreign investment, and short-term portfolio investments ("hot money"). While it has accommodated an increasing variety of non-bank financial institutions (e.g., hedge funds) and engulfed a growing number of countries by penetrating their domestic banking systems, global finance rests in the end on the shoulders of perhaps fifty or sixty universal banks dominating the entire system. Those "systemically important financial institutions" (SIFIs) operate like a cartel, extract large monopoly rents, combine different types of (indirect, market, and network) finance under one roof, reap in this fashion significant (scale, scope, and network) economies, are too big to fail, and enjoy uniquely privileged access to the monetary authorities. All this makes them special. They are the vector of a longstanding financialization trend in which the accumulation of financial assets, the dominance of financial motives, the relative size of the financial sector, and the dependence on external (debt) finance all become ever more important. ${ }^{10}$

We can look at this financialization trend as one of both financial concentration and financial centralization. The phenomenon of financial concentration occurs, when leading firms across a large number of sectors manage the decentralization of their production, in the formation of global supply chains, by exercising tighter control over their cash flows so that they end up collecting huge amounts of cash which they park in liquid financial assets. Those same firms also prefer an external growth strategy of acquiring existing productive assets in the stock market rather than build new capacity from scratch, as they seek to survive the transformation of their sectors into global oligopolies. Financial concentration also occurs when a growing proportion of the workers' income gets channeled as forced savings into private pension funds, and household savings become for the most part actively managed portfolios placed in funds rather than passively managed bank deposits kept at the local bank branch for long periods of time.

Within the broader financial concentration trend there is also a process of financial centralization at work. The finance sector becomes proportionately larger,

\footnotetext{
${ }^{10}$ For more on the financialization trend and its various empirical manifestations see Gerald Epstein (2005), Greta Krippner (2005), and Engelbert Stockhammer (2004).
} 
moving in the US from 2 percent of GDP in 1982 to 8 percent of GDP three decades later. That enlarged finance sector, directing much of its endogenous money creation towards the self-aggrandizement of its markets, networks, and institutions, has the power to absorb a disproportionately large portion of total private sector income. The US share of finance-sector income rose from a long-wave trough of 3.3 percent in 1982 of corporate profits to 41.8 percent at the onset of the 2007-08 crisis. This, of course, is paralleled by extraordinary income gains for bankers, traders, or hedge-fund managers, which even surpass the already outlandish CEO compensation packages in stock options and bonuses. As a result we have experienced a major shift in functional income distributions (from falling wage shares via stable industrial profit shares to rising financial income shares) and unprecedented inequality in personal income distribution, with the top 1 percent in the US absorbing nowadays 20 percent of all income and almost half of all the nation's wealth. ${ }^{11}$ And, as yet another aspect of financial centralization, the largest banks have seen spectacular gains in market share, with the share of the five largest US banks rising from 9.7 percent in 1990 to over 44 percent in 2013.

But when it comes to global finance, this financial concentration/centralization trend plays out within the institutional framework of our prevailing international monetary system. And here, when looking at the long-term evolution dynamic of that system, we have witnessed an opposite movement in the direction of monetary fragmentation ever since the collapse of Bretton Woods in 1971. The US dollar is no longer absolutely dominant as it was forty-five years ago (when it had a 90 percent market share as international medium of exchange), with its world-money status eroding gradually to a 50 percent market share. With the formation of the euro as Europe's single currency (adopted now in 18 countries) in 1999 and the accelerating deregulation of China's renminbi into a more or less convertible yuan since 2008 , the dollar has to contend with two potential challengers for worldmoney status in coming decades. But the monetary fragmentation away from the dollar monopoly goes beyond that to include other safe-haven currencies, such as the pound, Swiss franc, and yen, and has recently even extended to a range of socalled "resource currencies" issued by economies benefiting from the global boom in commodities, such as the Canadian, Australian, and New Zealand dollars, the South African rand, and the Brazilian real.

Besides moving from a single universal-money standard to a multi-currency regime, monetary fragmentation also occurs when there is a growing variety of exchange rate regimes being pursued by different governments, moving away from the spectral extremes of free floating and iron-clad peg towards the middle

\footnotetext{
11 Thomas Piketty (2014) has recently brought a much-discussed focus on the growing income and wealth inequality in the US and Europe. While his argument does not directly blame finance for this trend, it is not too far-fetched to extend his core relation between rates of return on capital and growth rates to include the biases and distortions financialization brings to this inter-relation.
} 
in the search for hybrid regimes promising the best of both worlds such as managed float or crawling peg. Yet another expression of monetary fragmentation, this one a post-crisis phenomenon, is the home-market bias of worried, crisisstricken investors rushing back to their domestic base while seeking to reduce their foreign exposure for fear of greater losses, regulatory clamp-downs, and new risks beyond their control. Finally, monetary fragmentation also occurs, once again as a more recent post-crisis phenomenon, in the implementation of reregulation efforts which, even though conducted on a global scale under the auspices of the Bank for International Settlements and the G-20's Financial Stability Board, differ greatly between nations and regions in terms of scope, timetable, and application to give rise to temptations among banks for regulatory arbitrage.

These dual tendencies of financial concentration and monetary fragmentation live in constant tension with each other, and those tensions play themselves out within the institutional construct of the post-Bretton Woods multi-currency system. On the one hand those tensions produce centripetal forces driving towards a recentering of the US dollar's dominance, as happened at key moments during the 2007-09 crisis triggering massive flights to safety into US Treasuries (to the point of them ending up with negative interest rates) even though the crisis emanated originally from the United States in the first place. On the other hand, the same tensions can also translate into centrifugal forces away from the US dollar towards moving capital to other players, even entire regions (EU, East Asia), and their currencies. The role of global finance is to mobilize and direct these simultaneous centripetal and centrifugal pressures towards a coherent growth pattern driving the world economy forward along its globalization path.

\section{CENTRIPETAL VERSUS CENTRIFUGAL FORCES IN THE GLOBAL GROWTH PATTERN}

Centripetal forces in the global growth dynamic focus on the dominant role of the US dollar in the international monetary system, which directs a disproportionate share of global capital flows towards the US economy. The dual role of the US dollar as national currency of the US economy and the world's still-dominant international medium of exchange is a matter of great asymmetry. The US does not have to worry about its currency's exchange rate and is better shielded than anyone else from the vicissitudes of the world economy, but at the same time its actions and beliefs have disproportionately large impact on everybody else. This is especially true with regards to the Fed's conduct of monetary policy, which can focus more exclusively on domestic concerns and less on international-economy considerations (like the exchange rate) than is the case for any other central bank in the 
world. But at the same time the Fed's decisions have a greater impact than anybody else on what is going on in the world economy. ${ }^{12}$

This asymmetry in impact is part of a broader seigniorage benefit accruing to the issuer of world money. That issuer needs to run chronic balance-of-payments deficits, by which its currency gets moved out of domestic circulation and flows to the rest of the world using it as reserve or to pay each other. Since foreigners need to get their hands on dollars, they are willing to finance America's external deficits automatically, continuously, and, if needs be, even at zero or in any case very low interest rates. During the Bretton Woods years (1947-1) America's external deficit came about by means of massive capital exports, which had to exceed then-chronic US trade surpluses. Those capital exports took the form of aid and assistance programs (e.g., Marshall Plan for Europe, Kennedy's Alliance for Progress with Latin America), a worldwide network of US-operated military bases encircling the Soviet Union, and aggressive foreign direct investment by US multinationals - all means to cement US power abroad while facilitating the catching up of other nations, hence a very good deal for both sides.

After dealing with the dramatic financial instability caused by the stagflation crisis of 1969-1982 and its disinflationary denouement in the early 1980s, the US began to run widening trade deficits amidst highly stimulative monetary and fiscal policies which it financed by importing lots of capital from the rest of the world. By 1985 the US had become a net debtor to the rest of the world, accumulating over the next three decades a foreign-debt load in excess of $\$ 4$ trillion. But this large external debt is not like any other country's, because America borrows from the rest of the world in its own currency. So it does not have to earn foreign currency to service this debt. It can instead just create ("print") its own money to service its foreign debt, usually just rolling it over upon maturity when repaying Treasuries coming due with new borrowings. This is a huge advantage, an "exorbitant privilege" indeed. ${ }^{13}$

Its currency's world-money status has thus in effect freed the US from any external constraint, allowing that country unlimited funding of its private-sector $(\mathrm{S}-\mathrm{I})$, budget $(\mathrm{T}-\mathrm{G})$ and foreign $(\mathrm{X}-\mathrm{M})$ deficits from the rest of the world. It thus could always pursue relatively more reflationary and stimulative macro-economic policies than other countries would be able to in the face of their respective external constraints, a policy bias enjoyed by both Republican (e.g., Nixon, Reagan, Bush Jr) and Democratic (Johnson, Clinton, Obama) administrations. Access to ample supplies of foreign capital has also allowed US financial markets to be deeper and proportionately bigger than elsewhere, a possible comparative advantage

\footnotetext{
${ }^{12}$ Excellent discussions of the dollar's world-money status and its asymmetric impact on monetary policy, giving the Fed a much greater degree of freedom than other central banks, can be found in C. Fred Bergsten (1996) and Stephan Schulmeister (2001).

${ }^{13}$ Barry Eichengreen (2011) is one of the few American economists having fully come to terms with this “exorbitant privilege" benefit the United States has reaped from its currency's international status.
} 
especially in the area of setting up new businesses or funding small- and mediumsized firms. But the large-scale capital inflows ultimately had a more pernicious longer-term impact on the macro-behavior of the US economy, namely turning it into an economy prone to asset bubbles whose wealth effect would stimulate economic activity greatly until they burst. This propensity for asset bubbles was also anchored by major policy changes, especially in the wake of the "Reagan Revolution" of the early 1980s which dramatically lowered the marginal tax rates for the top earners, reduced taxation of capital gains far below that of other income, set up tax-sheltered saving vehicles for retirement and other long-term projects (e.g., education, health, home-ownership), promoted the deregulation of finance as well as other hitherto heavily regulated sectors, reduced the intervention capacity of regulatory agencies, and promoted liberalization of trade and cross-border investments.

Since the Reagan Revolution of the early 1980s the US has experienced three major consecutive asset bubbles supported by foreign capital imports. The first of these was a stock-market bubble fuelled by a group of daring investors known as "raiders" who used a new funding instrument, so-called high-yield (or "junk") bonds, to attack undervalued US corporations with hostile take-over bids. Firms thus targeted either had to fend off attacks by paying the raiders handsomely or were taken over and dismembered to be sold off in pieces. Soon investors went into speculative frenzy about which companies would be the raiders' next takeover target, seeking to buy into those to profit from any subsequent attack. In addition, such attacks triggered more far-reaching restructuring efforts in the sectors concerned. That stock-market bubble of the mid-1980s imposed shareholder value maximization as the new dictate of corporate governance while promoting the post-stagflation reorganization of US industry across a wide range of sectors. The bubble burst with a stock-market crash in October 1987, linked to rising US interest rates pushed up by a concerted international effort under the so-called Louvre Agreement of February 1987 to establish target zones for the world's key currencies. ${ }^{14}$

Ironically, a significant portion of the global capital flows towards the United States during that first bubble in the mid-1980s consisted of debt-servicing charges of less developed countries to US banks which allowed those to slow down the write-off losses from non-performing loans to LDCs. This arrangement resulted from the way a major global financial crisis, the so-called LDC debt crisis, was handled after August 1982 when Mexico, Argentina, and Brazil — the three largest Latin American economies to whom the nine largest US banks had lent 220 percent of their bank capital - declared themselves in de-facto default. These countries, like many other developing countries at the time, had reached the limits of their nationalist import-substitution phase of their development in the 1970s when they

\footnotetext{
14 The Louvre Agreement, concluded among the seven leading economic powers of the world (United States, Britain, France, Germany, Japan, Canada, Italy) in February 1987, committed the central banks of those countries to take coordinated policy action in defense of target zones set for their exchange rates. The agreement led to some coordinated interventions and interest-rate adjustments, but lacked deeper cooperation commitments and so fell apart after the stock-market crash of October 1987.
} 
experienced two oil-price shocks in a row. The massive surplus of oil producers after the first price hike in October1973 was recycled through the Eurocurrency markets as loans to oil-importing nations. This petro-dollar recycling was further enlarged after the second price-hike in March 1979, but then rudely disrupted six months later when the Fed took on double-digit US inflation and a collapsing dollar by deregulating interest rates (which subsequently tripled to levels above 20 percent in a matter of just three weeks). LDC debtors suddenly faced a double whammy of much higher debt servicing charges on their variable-rate Eurocurrency loans and declining export earnings as the world succumbed to recession in the wake of the Fed's spectacular tightening move. And so about fifty or so LDCs found themselves in de-facto default at the height of the global recession in mid-1982, necessitating hasty construction of an IMF-led international lender of last resort to avoid imposing potentially devastating losses on leading US and European banks. ${ }^{15}$ This mechanism provided limited official assistance in exchange for fairly brutal policy-mix changes and regulatory reforms known as "structural adjustment programs" which would then assure private lenders sufficiently to accept slower repayment schedules and offer new loans. It is this debt-extension and -expansion strategy which led to the perverse situation of having impoverished debtors in the developing world provide during that period net outflows to the richest country in the world while themselves being pushed into deep-recession "adjustments" which took years to go through.

The IMF used its power as the creditors' police to impose on its assistanceseeking (and hence pretty desperate) clients a hard-line reform program of neoliberal policy prescriptions, known as the Washington Consensus. This program comprised fiscal austerity, privatization, deregulation, and full insertion into the world economy through systematic dismantlement of barriers to unfettered market regulation (implying a push for removal of trade barriers, capital and exchange controls, and currency-price manipulation). It is only in 1989, when a majority of the largest LDC debtors had made sufficient progress with their policy adjustments and reforms while also having given US banks enough time to cope with the recapitalization and loss-absorption challenges from non-performing LDC loans, that the crisis-manager troika of US Treasury, BIS, and IMF came up with a systemic solution to the debt-restructuring challenges facing dozens of debtor nations and their creditors, in the form of so-called Brady bonds. ${ }^{16}$ This innovation, while easing the debt-servicing burden of selected LDCs and giving both sides options to

\footnotetext{
${ }^{15}$ The LDC debt crisis necessitated creation of an international lender-of-last-resort mechanism which besides the International Monetary Fund's structural-adjustment programs, also drew on the US Treasury's Exchange Stabilization Fund and the Bank for International Settlements. Their combined intervention paved the way for renewed lending and debt-restructuring support from the Eurobanks.

${ }^{16}$ Brady bonds were dollar-denominated and US-backed bonds issued by troubled LDC debtors after 1989 to replace outstanding loans that could no longer be properly serviced. Since these bonds carried lower principal or yields, they offered LDCs debt reduction while giving their lenders an exit option. Not only did the Brady bonds end the debt crisis of the 1980s, but they also launched a (by now very
} 
negotiate outright debt reduction through loan-for-bond swaps, also had the added benefit of standardizing sovereign bonds of LDCs sufficiently to set the stage for the take-off of the so-called emerging-market bond market.

It is perhaps at this moment, in 1989, that LDCs become emerging-market economies (EMEs) as they get forcibly opened up and stabilized while pushing through irreversible structural reforms for fuller insertion into the world economy. In return they also regained access to international investors in the new EMB market. A good many of these countries took additional years of painful adjustments amidst hyperinflation and collapsed domestic production to achieve sustainable macro-economic stabilization, with Mexico's “Tequila crisis” or Brazil's new Plan Real marking 1994 as a crucial year for crisis resolution. That same year China, emerging from its post-Tiananmen Square turmoil, undertook significant tax, fiscal decentralization, and banking reforms while devaluing its currency in one swoop by 40 percent. These measures put the wakening giant onto an export-led and investment-driven growth path for the next two decades. And the European Union, having chosen a ten-year transition towards a single currency with the Maastricht Treaty of 1992, had survived more than a year of speculative attacks on its fixedrate Exchange Rate Mechanism (from July 1992 to September 1993) to start the necessary path towards convergence among its members at more realistic exchange rates which the currency markets had finally obtained in the resolution to that major currency crisis. ${ }^{17}$

These developments - the resolution of the LDC debt crisis, China's awakening, Europe's push for economic and monetary union - were part of an accumulation of centrifugal forces away from America's absolute dominance while broadening the reach of market-regulated capitalism. Underlying this trend was a larger transformation shaking the world in the early 1990s when three billion people, half of the world's population, joined global capitalism all at once. This demographic shock to the system did not just emanate from the collapse of the Soviet Union and its allies or China's dramatic insertion into the world economy, but also included such populous nations as India, Brazil, Indonesia, or Mexico all of whom exited their nationalist import-substitution phase of development with neo-liberal marketopening reforms and political change away from their traditional single-party states. Global finance played a huge role in that transition, both by imposing its policy preferences on all those newly emerging market economies while at the same time regulating their share of access to the world's financial capital - both in terms of savings and money-creation capacity. Global finance, in particular the network of

large) sovereign-bond market which has enabled emerging-market economies to access international capital supplies.

${ }^{17}$ The speculative attacks on the European Monetary System's fixed exchange rates, which had not been adjusted for nearly a decade and were to be locked in permanently in the transition to a single-currency zone, broke the EMS' Exchange rate Mechanism in September 1993. From then on the ERM's currencies were allowed a much wider 30 percent band of fluctuations, which enabled the weaker currencies in the system to make the necessary downward currency-price adjustments before locking their exchange rates. 
about 400 universal banks comprising the inter-bank market at its center, had the unique capacity of mobilizing both the centripetal flows towards the United States in support of its deficits and the centrifugal flows engulfing half of the world onto a new development path at the same time. Its two-way flow mobilization translated into a huge expansion of the capital accounts in the balance of payments of both the (thirty or so) advanced capitalist economies and the (fifty to sixty) EMEs.

These bi-directional financial flows had to pass through the international monetary system, an institutional framework of agreements, rules, and conventions that provides for a range of internationally acceptable world-money forms, trans-national payments and settlement systems (both public and private), the foreign-exchange market as the nerve center of the global economy, a range of possible exchange rate regimes (from free float to currency board), all of this organized around hierarchically structured power relations between nation-states representing different factions of capital. Think of the international monetary system as a sort of pyramid of monies and their issuers, with the US and its dollar at the top and barely convertible currencies of frontier economies (from Albania to Zimbabwe) at the bottom, with lots of movement between and within its six layers - the dollar layer, the challenger layer (euro, yuan), the safe-haven layer (yen, franc, pound), the resourcecurrencies layer (real included), the convertibility-restoration layer (most currencies of countries trying to find their place in the world economy), and the repressedcurrency (including dollarization or euroization) layer of still mostly poor frontier economies. Of course, what interests us here the most is what is happening in and with the resource-currencies layer as Brazil is right in the middle of it.

First, however, we have to look at the origins of that resource-currencies layer and find it among the "Asian Tigers" along the Pacific Rim from Thailand via Vietnam up the coast to South Korea and extending to the island nations of Indonesia, Philippines, and Taiwan. Their resource was (and continues to be) a young, eager, fairly well educated, multi-lingual labor force ready to do its part in the global supply chains of Western or Chinese multi-nationals. When those countries' hundreds of millions entered global capitalism, they did so - as in China first as workers and only then as consumers. By the mid-1990s Eastern Asia's Pacific Rim had become a highly dynamic zone of rapid growth attracting investors from all over the world, with Hong Kong and Singapore the financial hubs distributing the billions flowing into the region among rapidly growing economies from Thailand to South Korea. While the world was paying more attention to China's spectacular take-off, the so-called "Asian Tigers" racked up similarly high growth rates. In some instances the massive capital inflow set off asset bubbles. But even without that cyclical destabilizer the boom in Eastern Asia would not have lasted much longer, as its economies overheated, inflation rose, debt levels became unsustainable, and their current account balances deteriorated amidst a rising US dollar to which those currencies were for the most part pegged. Add to this tremendous competitive pressure from China after its 1994 devaluation.

By mid-1997 the situation had become precarious in the entire region as central bank after central bank used up rapidly shrinking foreign-exchange reserves to 
defend ultimately indefensible currency pegs. When that effort finally failed in one country, the botched devaluation of the Thai baht on July 2, 1997, all hell broke loose. There was a huge explosion of capital flight and speculative attack hitting the region's currencies all at once, breaking their pegs and then rendering local debtors and banks insolvent when those had to match their dollar-denominated liabilities with suddenly sharply devalued local-currency assets. Truly unprecedented was the speed, scale, and contagion scope of this capital flight, the result of a fundamental change in the nature of global finance. The investors were now for the most part (mutual, pension, hedge) funds, able to dump their securities at will. Commercial banks, on the other hand, do not have such an exit option, having to keep non-performing loans on their books and work out debt-restructuring deals with their impaired debtors over a good number of years (see the LDC debt crisis of the 1980s). So this "Asian crisis" of 1997-98 was the first global crisis of "market finance" and as such had a violence all of its own. It required rapid reaction, which consisted of huge bail-out packages by the IMF and swift enactment of stabilization measures whose initial extremism (65 percent interest rate in Indonesia!) caught everybody's attention and pushed policy reaction into a more pragmatic direction. But while individual East Asian economies managed for the most part to stabilize their traumatized economies within a year or two, helped by booms in China and the United States, the crisis moved on. First it knocked Russia into default in August 1998, which in turn triggered the collapse of legendary hedge fund Long Term Capital Management and a bail-out by its Wall Street brethren. Then still-sceptical speculators tested the will and strength of Brazil (with preventive assistance from the IMF) in January 1999. Finally the speculators went after the dollar-peso currency board of Argentina which, hitherto considered more or less unbreakable, proved in December 2001 to be breakable after all.

This crisis too coincided with a US bubble, just as the one in the 1980s. The bubble, which formed in early 1997 around the high-tech stock market known as Nasdaq, was caused by investor enthusiasm for the likely commercial impact of the internet. That euphoria grew into a folly during 1999 when the fear of the "Y2K bug" fueled huge corporate spending on new computer systems while internet entrepreneurs launched one spectacular initial public offer after another, turning them and their venture-capital supporters into multi-billionaires overnight. It was in March 2000, after the Y2K bug had proven a hoax, that the bubble collapsed. As is the case in many financial crises, this one too served the useful purpose of weeding out the mad and the weak to leave behind a battle-tested "hard" core on both sides of the ledger (producer and financier) learning from mistakes to make their engagements more resilient. That is exactly what also happened to the "junk" bonds and the corporate raiders after the collapse of the first bubble a dozen years earlier. This second bubble pushing the internet was, however, less dependent on foreign capital inflows and more of a home-grown phenomenon even though US current account deficits reached a record $-3.6 \%$ in 1999 and $-4.4 \%$ in 2000 in support of the emerging-market economies trading their way out of their crisis. The subsequent bubble-burst recession of 2000-01 was made worse by the 9/11 attack, but the Fed 
and Bush both pushed the gas pedal (with super-low interest rates and large increases in US budget deficits) to achieve a sustainable recovery by the end of 2002 .

It is at that moment, in 2002-03, when the synchronized onset of sustainable recoveries in both the center (US) and the periphery (emerging-market economies), together with the successful start of the eurozone, yielded a constellation of upswing forces that intertwined centripetal and centrifugal flows in particularly powerful forward motion. US multinationals and funds invested heavily overseas, especially in emerging-market economies eager to become part of the global supply chain that transformed multi-national enterprises into global production networks operating at a higher level of globalization. ${ }^{18}$ But even more financial capital flowed the other way, with European banks getting hooked after 2005 to the high-yielding, but supposedly super-safe US mortgage-backed securities while central banks of emergingmarket economies bought huge amounts of US Treasuries in their attempts to hold down their now-undervalued currencies so that their export-led booms could continue unabated. Out of this flow matrix was born the US housing bubble of 2003-07 which, by means of a massive loan-securitization machine of increasing complexity and scale, allowed a rapidly growing number of American homeowners to use their habitats like an automated teller machine at a bank to draw cash from whenever they liked. This was a self-feeding bubble inasmuch as rising real-estate prices enabled Americans to refinance their mortgages with larger principals in line with the appreciation of their collateral or take out additional home-equity loans against their houses which they could spend on anything. In that sense Americans became the buyers of last resort for the rest of the world, allowing both advanced capitalist economies (e.g., Germany, Japan) as well as emerging-market economies (e.g., China, Brazil) to pursue export-led growth strategies. Eventually the US current account deficit (approaching at the peak $7 \%$ of US GDP) would absorb three-quarters of the rest of the world's current account surpluses, the latter being pretty much automatically recycled back to the US for this mutually serving arrangement between privileged debtor and needy creditors to continue.

But this "iron embrace" could not go on forever. To the extent that the globally financed loan-securitization machine feeding this bubble ultimately needed a steadily growing number of American mortgages securitized, US banks pushed a variety of non-traditional, high-risk mortgages towards segments of the population that had been excluded from such credit access so far, including so-called subprime mortgages which began to destabilize the loan-securitization machine in early 2007 when there was a spike in defaults as refinancing of those riskier loans stopped with home-price appreciation reaching its ceiling. The subsequent disintegration of this

\footnotetext{
${ }^{18}$ Multinational firms organize regionally, with different products for each region (e.g., General Motors' Chevrolet or Cadillac in the US, Opel and Vauxhall in Europe). Global production networks operate on the other hand globally, offering the same standardized products worldwide (e.g., Ford's Fiesta or Taurus) while locating the production of different parts and components where the required combination of resources yields the greatest comparative advantage (e.g., engineering in Germany, industrial design in Italy, labor-intense assembly in low-wage countries like Mexico or China).
} 
funding machine, in the so-called subprime crisis, set off runs on particularly exposed lenders (e.g., Bear Stearns, Countrywide, Washington Mutual, Fannie Mae and Freddie Mac, Merrill Lynch) all the way to the bankruptcy of Lehman Brothers in mid-September 2008 triggering a panic run in the world's money markets which pushed the global economy into a depression-like downturn. The worst was only averted by massive, coordinated government intervention in the G-20, comprising bank bailouts and recapitalization, fiscal stimulation packages, and unorthodox monetary policies at the zero-bound known as "quantitative easing." 19

The emerging-market economies, Brazil included, survived the systemic crisis of 2007-08 surprisingly well, with only a relatively minor trade-induced recession pause interrupting their rapid-growth path soon to be resumed. Part of that resilience was due to their strong internal growth momentum, further reinforced by high commodity prices (a boost for their EME suppliers, such as in the case of Brazil in terms of foodstuffs, oil, iron ore, etc.), their cushion of large foreign-exchange reserves, and deft domestic policy stimulation. But another reason were the growing South-South trade- and investment-flow ties among EMEs, shaken for a little while by the collapse of trade credit, but then resuming strongly. In general, the EMEs were for the first time as a bloc capable of providing a net stimulus to the world economy in times of crisis.

But that new role also brought new challenges, most notably EMEs becoming targets of carry trade where investors borrow dollars at near-zero rates to invest in higher-yielding EME instruments and so drive the exchange rates of EME currencies upwards. Brazil's finance minister Guido Mantega was correct in characterizing this situation as one of "currency war" in 2009, because the EMEs would not be able to sustain export-led growth if currency appreciation priced them out of the world markets. Carry trade also made EMEs subject to greater currency-price volatility, with sudden reversals a distinct prospect whenever global investors became nervous about the Fed's intentions with regard to quantitative easing. Brazil also pioneered new capital controls, especially in the form of taxing short-term foreign inflows, with mixed success. EME central banks have also been trying to keep down inflationary pressure arising from all those capital inflows, again with at best mixed success. And those very central banks also have had to get prepared for seeing their EME currencies - from China's yuan to Brazil's real — gradually internationalize their circulation outside of their country of issue. To the extent that the EMEs, in particular the BRICS - Brazil, Russia, India, China, and South Africa - see their global role rising, they will want to get better representation in the multilateral institutions of global economic and monetary governance. But reforms to that effect of the IMF in particular have stalled, motivating the BRICS to go it alone (as exem-

\footnotetext{
${ }^{19}$ Quantitative easing, practiced in particular by the Fed, the Bank of England, and the Japanese central bank, involves massive bond purchases by those monetary authorities which in turn blow up the money supply and thus maintain super-low interest rates. For more on the 2007-09 crisis and its aftermath see Robert Guttmann (2008, 2009).
} 
plified most recently by formation of the BRICS Bank in July 2014). All this presents a highly challenging post-crisis environment for EME governments (e.g., Brazil's Rousseff administration). The true challenges are in the end structural in nature.

\section{THE EXCHANGE RATE: A MOST STRATEGIC PRICE}

It is the exchange rate which establishes the deepest link between the domestic economy and the rest of the world, determining the former's insertion in the world economy and hence shaping its growth dynamic. This crucial macro-economic variable should not be left to market forces alone, because those tend to create two major problems for emerging-market economies — too high a currency price and too volatile its fluctuations. But if such a "free float" is too costly, what alternative exchange rate regime should emerging-market economies opt for? The other extreme, an iron-clad peg, does not work well either. As we have seen from the repeated currency crises of the 1980s and 1990s, pegs are there to be broken. This leaves us with a hybrid approach combining market regulation with a good deal of central bank intervention, which those emerging-market economies with a large foreign-reserve cushion (like Brazil or China) are quite capable of implementing and sustaining over the long haul.

China, with its huge reserves and still highly restrictive capital controls, practices a more interventionist "crawling peg" regime that is also more costly in the sense that it requires large purchases of low-yielding dollar-based US securities to sustain (and these may be considered a wasteful use of resources while also leaving the country quite vulnerable to the vicissitudes of the dollar). Brazil has used a more flexible "managed float" regime in recent years, reinforced with a battery of new capital controls to slow excessive capital inflows. One question is whether these work effectively (probably to some degree) while the other question pertains to their long-term effects (more problematic in terms of potential distortions). What strikes me as important, and potentially as effective as capital controls, is to have an activist central bank which changes the rules of the game occasionally to confuse market expectations and hurt speculators - as the People's Bank of China has done quite masterfully in recent years.

Even more important than the dance between central bank and speculators is the question of the exchange rate level. Given the dollar's low-level bias and intense competition among the BRICS and other EMEs in pursuit of their respective export-led growth strategies, it is crucial that a large EME's central bank, like the Banco Central do Brasil, target a sufficiently low level for its currency even to the point of occasionally intervening to push the exchange rate down. ${ }^{20}$ This is easier

\footnotetext{
${ }^{20}$ It is in this context worth noting that Brazil's Banco Central has recently intervened quite massively, to the tune of $\$ 90$ billion worth of currency-swap auctions and credit lines for dollars, to push the effective exchange rate of the real up rather than down. If this was meant as a strategy against the build-up of inflationary pressures, this intervention has not worked (except as to say that the decline
} 
said than done, because of the "Dutch Disease" problem (which is particularly endemic to Brazil's economy). Market forces set exchange rate levels according to your primary export products, and if you are richly endowed with high-demand natural resources (e.g., oil, iron ore, agricultural products) then those products will set an exchange rate that is simply too high for your less-dominant manufacturing sector. This means in practicality that an EME economy, like Brazil, is made up of different sectors having divergent needs and exposures pertaining to the level of the exchange rate, which obliges that country's central bank to target an effective exchange rate with the country's main trading partners that is lower than the speculation-driven markets consider appropriate. The question for the central bank is then how best to manage that tension.

Part of the central bank's work is to figure out reasonable and sustainable exchange rate levels to aim for, best done in not-too-rigid fashion as a band of, say, plus and minus 10 percent around a target level. This requires it to calculate, or at least have a good sense of, the "equilibrium" (or "universal value") level of the currency price, usually best expressed in terms of real effective exchange rate measuring the inflation-adjusted exchange rate against a weighted basket of currencies from that country's major trading partners." Standard measures will no longer do for this calculation. The purchasing-power-parity concept, applying to the current account, is no longer used as an absolute measure, because it has simply proven too difficult to construct reliably comparable price indices (based on the same or similar baskets of goods and services) across countries. So we use it only as a relative measure, based on inflation-rate differentials of countries whose currencies we are linking, only to note that those differences rarely, if ever, yield predictable measures of currency-price adjustments. Even worse is the notion of (uncovered or covered) interest rate parity to explain currency-price levels for the capital (or "financial") account. We do not know what interest rate to pick for purposes of comparison when we have cross-border flows covering the entire yield-curve spectrum. And in addition we have more and more portfolio investments motivated not by interest rate differentials, but by other types of financial income, in particular dividends and capital gains. Speculation, the dominant force in global finance, is mostly attracted by the imminent prospect of capital gains and fed by momentum into overshoot patterns of strong ups and downs that completely defy the narrow scope of the U/CIP equilibrium.

Luckily, post-Keynesians have given us better concepts of equilibrium exchange rates to calculate. I am thinking here in particular of two promising new measures. The first is the "fundamental equilibrium exchange rate" (FEER), introduced by John Williamson (1994) and now subject to regular estimates for the key currencies by his Peterson Institute of International Economics. ${ }^{21}$ The beauty of FEERs is that

of the real and its inflation could have been quite a bit worse without those measures over the last couple of years).

${ }^{21}$ See piie.com, in particular the regular estimates of FEERs under the direction of William Cline. The 
they are modeled to take account of external (current account) balance and internal (output-gap) balance, aiming for an exchange rate level yielding sustainable ranges for both at the same time. Those FEER models thus take account of variables affecting the (equilibrium) current and capital (or "financial") account balances while also looking at factors influencing the private-sector balance of savings and investments for determination of aggregate spending levels within the domestic economy, including spillovers from the public sector such as fiscal consolidation. My criticism with the FEER calculations typically found at the PIIE or the CEPN is that they may well underweight the internal-balance needs in their two-sector models. And it may be possible to break down the internal sector by industrial matrix, recognizing that advanced capitalist or emerging-market economies are made of distinct parts each of which with a different exposure to international competition - agriculture, other commodities, intermediate goods (for participation in global supply chains), finished goods (merchandise trade), tradeable and non-tradeable services. You can calculate FEERs for each sector, and then take the weighted average of those calculations as the right macro-level measure.

Such sectoral weighting may actually be more easily calculated with an alternative measure known as "behavioral equilibrium exchange rate" (BEER), first introduced by Peter Clark and Ronald McDonald (1998; 2000). The BEER models, in contrast to their FEER brethren, focus predominantly on variables affecting the relative prices of traded to non-traded goods at home and in foreign countries. Those may include different productivity trends in traded goods sectors or asymmetric terms-of-trade shocks. In any case, the structure of BEER models may lend itself better to the necessary disaggregation taking account of the multi-sector nature of economies in a highly globalized context. ${ }^{22}$

\section{REFERENCES}

Adler, M. \& Hufbauer, G. C. (2008). "Policy liberalization and FDI growth, 1982-2006", Peterson Institute for International Economics Working Paper 8-7, 2008.

Bergsten, C. F. (1996). The Dilemmas of the Dollar. Armonk, NY: M.E. Sharpe.

Clark, P. \& McDonald, R. (1998). "Exchange rates and economic fundamentals: A methodological comparison of BEERs and FEERs". IMF Working Papers no. 98/67.

Centre d'Economie Paris Nord, where I work, also uses the FEER concept in its analysis and for modelbased estimates (see here the work of Jacques Mazier with his research staff, such as Jamel Saadaoui, 2012).

${ }^{22}$ The BEER models refined by Ron McDonald, Pete Clark and others have typically included among fundamental variables a comparison of net exports as proportion of GDP, a real-interest differential, a terms-of-trade differential, a GDP-per-capita differential between the countries concerned. The calculation of the "foreign" magnitudes in those differentials uses typically trade weights found for the baskets used in the calculation of effective exchange rates. The models then proceed to estimate BEER values through both single-county and panel econometric methods. 
Clark, P. \& McDonald, R. (2000). "Filtering the BEER: A permanent and transitory decomposition". IMF Working Papers no. 00/144.

Eichengreen, B. (2011). Exorbitant Privilege: The Rise and Fall of the Dollar and the Future of the International Monetary System. New York: Oxford University Press.

Epstein, G. (2005). Financialization and the World Economy. Cheltenham, UK: E. Elgar.

Frydl, E. (1982). “The Eurodollar Conundrum. Federal Reserve Bank of New York Quarterly Review $7(1), 11-19$.

Guttmann, R. (1994). How Credit-Money Shapes the Economy: The Unites States in a Global System. Armonk, NY: M.E. Sharpe.

Guttmann, R. (2008). “A primer on finance-led capitalism and its crisis. Revue de la Régulation,\#3-4, (regulation.revues.org/document5843.html).

Guttmann, R. (2009). “Asset bubbles, debt deflation, and global imbalances”. International Journal of Political Economy, 38(2), 45-68.

Guttmann, R. (2015). Finance-Led Capitalism: Shadow Banking, Re-Regulation, and the Future of Global Markets. New York: Palgrave Macmillan.

Johnson, S. \& Kwak, J. (2010). 13 Bankers: The Wall Street Takeover and the Next Financial Meltdown. New York: Pantheon Books.

Krippner, G. (2005). “The financialization of the American economy”. Socio-Economic Review, 3(2), $173-208$

Lerner, A. (1952). "Factor prices and international trade”. Economica 19(73), 1 -15.

Magee, S. (1973). "Currency contracts, pass-through, and devaluation". Brookings Papers on Economic Activity, no. 1, 303-325.

Marshall, A. (1879/1930). The Pure Theory of Foreign Trade, The Pure Theory of Domestic Values. London: London School of Economics and Political Science.

Philips, K. (2008). Bad Money: Reckless Finance, Failed Politics, and the Global Crisis of American Capitalism. New York: Viking Books.

Piketty, T. (2014). Capital in the Twenty-First Century. Cambridge, MA: Harvard University Press.

Saadaoui, J. (2012). "Global imbalances: Should we use fundamental equilibrium exchange rates? CEPN Working Paper 2012-07, Université Paris XIII, (http://www.univ-paris13.fr/cepn/IMG/pdf/ wp2012_07.pdf).

Schulmeister, S. (2000). "Globalization without global money: the double role of the dollar as national currency and world currency". Journal of Post Keynesian Economics, 22(3), 365-395.

Stockhammer, E. (2004). "Financialisation and the slowdown of accumulation". Cambridge Journal of Economics, 28(5), 719-741. 